Acta Universitatis Nicolai Copernici • Pedagogika XXXI/2015

Nauki Humanistyczno-Społeczne • Zeszyt 426

DOI: http://dx.doi.org/10.12775/AUNC_PED.2015.009

\author{
Kamila Majewska \\ Wydział Nauk Pedagogicznych \\ Uniwersytet Mikołaja Kopernika
}

\title{
DZIENNIK ELEKTRONICZNY \\ W PRACY NAUCZYCIELA
}

W

Tprowadzenie narzędzi technologii informacyjnej do szkół było jednym z elementów stanowiących o przemianie związanej z funkcjonowaniem systemu oświaty. Przekształcenia zapoczątkowane w latach 90. przez Ministerstwo Edukacji Narodowej znalazły swoje odzwierciedlenie również $\mathrm{w}$ zapisach legislacyjnych ${ }^{1}$. Zgodnie $\mathrm{z}$ wdrożonymi rozporządzeniami nauczyciele zostali zobowiązani do „stwarzania uczniom warunków do nabywania następujących umiejętności: poszukiwania, porządkowania i wykorzystywania informacji z różnych źródeł oraz efektywnego posługiwania się technologią informacyjną i komunikacyjną"2. Wymóg stosowania technologii informacyjnej w pracy pedagoga regulowała także dokumentacja dotycząca uzyskiwania stopni awansu zawodowego. Pomimo upływu lat

1 M. Rostkowska, Standardy przygotowania każdego nauczyciela $w$ zakresie technologii informacyjnej, „Meritum”, 2007 nr 4 (7), s. 14-18.

2 Rozporządzenie Ministra Edukacji Narodowej i Sportu z 26 lutego 2002 roku w sprawie podstawy programowej wychowania przedszkolnego oraz kształcenia ogólnego w poszczególnych typach szkół, http://isip.sejm.gov.pl/DetailsServlet?id=WDU20020510458 (dostęp: 23.11.2015). 
oraz wprowadzenia kolejnych aktów zmieniających kryteria odnośnie do włączania technologii informacyjnej w przebieg lekcji, kryteria dotyczące stosowania narzędzi komputerowych zarówno podczas lekcji, jak też w trakcie jej przygotowania zostały zachowane. Standardy te wskazują obowiązki, jak też nakreślają drogę rozwoju aktywnym zawodowo pedagogom ${ }^{3}$.

W wyniku zarysowanych powyżej przemian placówki edukacyjne zaczęto wyposażać $\mathrm{w}$ pracownie komputerowe $\mathrm{z}$ odpowiednim oprogramowaniem. Z czasem zasób narzędzi TI dostępnych w szkołach był wzbogacany. Obecnie obok komputerów w murach szkolnych stosuje się między innymi: tablice interaktywne, tablety, piloty elektroniczne, multibooki oraz dzienniki elektroniczne. Urządzenia te w zależności od wewnętrznego oprogramowania oraz zamysłu producenta mogą odgrywać różne role. Szeroko zakrojone badania prowadzone regularnie od 1992 roku przez pracowników Katedry Dydaktyki i Mediów w Edukacji Uniwersytetu Mikołaja Kopernika wykazują jednoznacznie, że odpowiednio wykorzystane narzędzia technologii informacyjnej ułatwiają nie tylko multimedialny, ale również interaktywny przekaz wiedzy ${ }^{4}$. Pomagają w procesie kształcenia na odległość 5 . Ułatwiają nabywanie umiejętności informacyjnych ${ }^{6}$. Umożliwiają dostosowanie materiałów dydaktycznych do potrzeb różnorodnych sensorycznie odbiorców ${ }^{7}$. Pobudzają kreatywność oraz pracę o charakterze twórczym ${ }^{8}$.

${ }^{3}$ M. M. Sysło, Standardy przygotowania nauczycieli $w$ zakresie technologii informacyjnej i informatyki, „Komputer w Szkole” 2003, nr 3.

${ }^{4}$ K. Majewska, Jak nauczać interaktywnie, „45 Minut”, 2012, s. 11-13.

5 W. Kwiatkowska, Wykład $w$ kształceniu na odległość, Toruń 2011.

6 M. Skibińska, Rola oprogramowania open source $w$ ksztatceniu umiejętności informacyjnych uczniów, w: Informatyczne przygotowanie nauczycieli: kompetencje i standardy kształcenia, oprac. J. Migdałek i M. Zając, Kraków 2006, s. $376-383$.

7 K. Majewska, Tablica interaktywna $w$ procesie nauczania wczesnoszkolnego, Toruń 2015 (w druku).

8 D. Siemieniecka, Metoda projektów $w$ budowie i realizacji systemu ksztatcenia studentów, Toruń 2012. Zobacz też: D. Siemieniecka, Media a twórczość, w: Edukacja medialna $w$ społeczeństwie informacyjnym, pod red. S. Juszczyka, Toruń 2004, s. 76-81. 
Podnoszą motywację oraz aktywność uczniów ${ }^{9}$. Dzięki nim prostsza oraz bardziej naturalna staje się realizacja procesu nauczania oraz uczenia się zgodna z teorią kognitywno-konstruktywistyczną ${ }^{10}$ oraz konektywistyczną ${ }^{11}$. Stworzone z myślą o szkole narzędzia TI usprawniają proces weryfikacji wiedzy oraz umiejętności, opracowywania materiałów dydaktycznych i testów wiedzy ${ }^{12}$, przygotowywania wszelkiego typu zestawień itp. W konsekwencji literatura przedmiotu przypisuje im następujące funkcje: informacyjną, ćwiczeniową, kontrolną oraz organizacyjną ${ }^{13}$, które w związku z pojawieniem się w klasach szkolnych e-dzienników należy dodatkowo poszerzyć o funkcję wychowawczą.

9 K. Majewska, Tablica interaktywna $w$ procesie nauczania, „Wychowanie na co dzień”, nr 6 (213), s. 28-31. Zobacz też: K. Majewska, The Interactive whiteboard in working with learners. Unconditional love, or a result of specific actions?, „Kultura i Edukacja” 2014, nr 5.

10 J. Piaget, Studia z psychologii dziecka, tłum. T. Kołakowska, Warszawa 2006; J. S. Bruner, Poza dostarczone informacje. Studia z psychologii poznawania, tłum. M. Mroziak, Warszawa 1978; L. S. Wygotski, Wybrane prace psychologiczne II - dzieciństwo i dorastanie, pod red. A. Brzezińskiej, M. Marchowa, tłum. A. Brzezińska, T. Czub, Sz. Hejmanowski, S. Jabłoński, M. Kurczewska, M. Marchow, B. Smykowski, Poznań 2002. Zobacz też: B. Siemieniecki, Kognitywistyka a edukacja medialna, w: Współczesna technologia informacyjna i edukacja medialna, pod red. T. Lewowickiego, B. Siemienieckiego, Toruń 2004.

11 G. Siemens, Connectivism: A Learning Theory for the Digital Age, 2004, http://www.elearns-pace.org/Articles/connectivism.htm (dostęp: 20.11.2015). Zobacz też: Young people's digital everyday life and education: new forms of self-formation, learning and digital literacy, pod red. E. Bratlanda, D. Siemienieckiej, Toruń 2012.

12 K. Majewska, Komputerowy system egzaminowania, „E-mentor” 2015, nr 1(58).

13 J. Morbitzer, Edukacja wspierana komputerowo a humanistyczne wartości pedagogiki, Kraków 2007, s. 45. Zobacz też: B. Siemieniecki, Edukacja humanistyczna i komputery, w: Edukacja medialna, pod red. J. Gajdy, S. Juszczyka, B. Siemienieckiego, K. Wenty, Toruń 2004. 


\section{ROLA E-DZIENNIKA W PRACY NAUCZYCIELA}

Szczególne znaczenie w przypadku funkcji organizacyjnej odgrywają, wprowadzone do szkół na podstawie Rozporządzenia Ministra Edukacji Narodowej z dnia 29 sierpnia 2014 r. w sprawie sposobu prowadzenia przez publiczne przedszkola, szkoły i placówki dokumentacji przebiegu nauczania, działalności wychowawczej i opiekuńczej oraz rodzajów tej dokumentacji ${ }^{14}$ dzienniki elektroniczne. Zgodnie z zapisami Ministerstwa Edukacji Narodowej i Sportu mianem dziennika elektronicznego określa się narzędzie, które:

- dzięki odpowiedniemu oprogramowaniu gwarantuje selektywność dostępu do danych (umożliwiając wgląd do bazy jedynie osobom do tego uprawnionym);

- umożliwia zapis oraz kopiowanie danych (przez co chroni je przed utratą, zniszczeniem lub uszkodzeniem);

- odpowiednio zabezpiecza dane przed dostępem osób nieuprawnionych (np. za pomocą hasła);

- rejestruje każdorazową modyfikację danych;

- umożliwia eksport bazy (zestawienia ocen, absencji itp.) do formatu XML;

- pozwala na przygotowanie dokumentacji w formie papierowej ${ }^{15}$.

Głównym założeniem przyświecającym procesowi wyposażania szkół w e-dzienniki było poprawienie komfortu pracy pedagogów. Narzędzie to umożliwia bowiem nieograniczony dostęp do dokumentacji, dzięki czemu osiągalna staje się analiza danych w dowolnym czasie, miejscu, a nawet przez kilku nauczycieli jednocześnie. Dodatkowo, dzięki wewnętrznemu oprogramowaniu, urządzenie automatycznie generuje zestawienie ocen, frekwencji lub innych statystyk związanych z procesem edukacji.

14 Internetowy System Aktów Prawnych, http://isap.sejm.gov.pl/DetailsServlet?id=WDU20140001170 (dostęp: 12.11.2015).

15 Internetowy System Aktów Prawnych. 
Wymienione powyżej funkcje, zwłaszcza z organizacyjnego punktu widzenia, są niezmiernie cenne. Ich wartość wynika głównie z usprawnienia działań pedagoga. Zgodnie z uwagami nauczycieli czas niezbędny do wywiązania się z obowiązków, których wykonanie na podstawie dostępu do tradycyjnego, papierowego dziennika zajmowało kilka godzin, został obecnie zredukowany do kilku minut. Przykładem wspomnianych usprawnień jest proces przygotowania sprawozdań oraz materiałów informacyjnych na wywiadówki lub Rady Pedagogiczne. W konsekwencji, jak zauważa Monika Wróbel, elektroniczny dziennik stwarza szansę na „prowadzenia pełniejszego nadzoru nad postępami w pracy uczniów"16. Ponadto e-narzędzie umożliwia wydruk świadectw lub eksport danych do programów przeznaczonych do ich przygotowania.

Analizując rolę dziennika elektronicznego pod kątem funkcji wychowawczej, należy zaakcentować, że szczególne znaczenie odgrywa tu stały, aktywny kontakt nauczyciela z opiekunami ucznia ${ }^{17}$. Zalogowanie na indywidualnie utworzonym koncie pozwala rodzicom na zapoznanie się z frekwencją oraz uwagami wystawionymi dziecku. Możliwe jest także wykupienie opcji, dzięki której wewnętrzne oprogramowanie e-dziennika wysyła pod wskazany numer krótką wiadomość tekstową, informującą o nieobecności dziecka na lekcji ${ }^{18}$. Stały dostęp do zapisów w dokumentacji szkolnej oddziałuje również na poprawę wyników nauczania oraz poziom przygotowania się do zajęć.

${ }^{16}$ M. Wróbel, E-dziennik jako narzędzie wspierajace proces edukacji szkolnej, „E-mentor” 2009, nr 4 (31).

17 Jak rodzice oceniają dzienniki elektroniczne - wyniki ankiet wśród rodziców, https://dziennik.librus.pl/pliki/gazeta_szkolna_2009_11_24_jak_rodzice_oceniaja_dzienniki_elektroniczne_wyniki_ankiety_wsrod_rodzicow.pdf (dostęp: 15.11. 2015$)$. Forum dla nauczycieli. 45 Minut, E-dziennik - zalety $i$ wady, http://www.45minut.pl/forum/viewtopic.php?t=9790 (dostęp: 15.11.2015). Forum dla nauczycieli. 45 Minut, Dziennik elektroniczny, http://www.45minut.pl/ forum/viewtopic.php?t=14143 (dostęp: 15.11.2015).

18 Doradca Dyrektora, Opłaty za dostęp do dziennika, https://www.librus.pl/ doradca-dyrektora/pytania-i-odpowiedzi/oplaty-za-dostep-do-dziennika/ (dostęp: 15.11.2015). 


\section{Metodologia Badañ*}

W roku szkolnym 2014/2015 oraz 2015/2016 (w ramach grantu 2210-NP) przeprowadzone zostały badania dotyczące wykorzystania elektronicznego dziennika przez nauczycieli z poziomu edukacji wczesnoszkolnej ${ }^{19}$. Analiza statystyczna przeprowadzona została na podstawie danych o charakterze ilościowo-jakościowym. Badaniu poddano 126 nauczycieli z poziomu edukacji wczesnoszkolnej, wytypowanych losowo ze szkół znajdujących się na terenie województwa kujawsko-pomorskiego. W celu zgromadzenia danych autorka skorzystała $\mathrm{z}$ ankiety oraz wywiadu ${ }^{20}$, koncentrujących się na zagadnieniu związanym z akceptacją pracy z narzędziem, formą oraz sposobem jego wykorzystania. Podczas wywiadów starano się również ustalić podstawowe problemy występujące podczas użytkowania e-dziennika. W konsekwencji wyróżniono cele badawcze:

1. Analizę oraz ocenę poziomu akceptacji e-dziennika przez nauczycieli edukacji wczesnoszkolnej.

2. Analizę oraz ocenę formy, a także stopnia wykorzystania e-dziennika w procesie wychowania uczniów.

W rozwiązaniu powyższych celów miały pomóc następujące problemy oraz pytania szczegółowe:

1. Czy i na jakim poziomie nauczyciele edukacji wczesnoszkolnej akceptują pracę z e-dziennikiem?

1.1. Czy i jaki procent nauczycieli edukacji wczesnoszkolnej akceptuje zmiany związane z wprowadzeniem e-dziennika?

1.2. Czy istnieje związek pomiędzy wiekiem nauczycieli edukacji wczesnoszkolnej a poziomem akceptacji e-dziennika?

* Metodologia oraz wyniki badań pilotażowych zostały opisane w artykule K. Majewskiej, Electronic class register in the process of teaching and upbringing, w: New Technologies in Education and Communication, pod red. D. Siemienieckiej, Toruń 2015.

19 Źródło finansowania badań - grant 2210 - NP.

20 K. Rubacha, Metodologia badań nad edukacją, Warszawa 2008. 
1.3. Czy i jaki procent nauczycieli edukacji wczesnoszkolnej ma problemy zwiazane z obstuga e-dziennika?

2. Czy i w jaki sposób nauczyciele edukacji wczesnoszkolnej wykorzystują e-dziennik $\mathrm{w}$ procesie wychowania?

2.1. W jakim celu nauczyciele edukacji wczesnoszkolnej wykorzystuja e-dziennik $w$ praktyce?

2.2. Czy i jak często nauczyciele edukacji wczesnoszkolnej wykorzystują e-dziennik $w$ celu informowania prawnych opiekunów dzieci o sytuacji szkolno-wychowawczej uczniów?

2.3. Czy informacje przekazywane prawnym opiekunom ucznia za pomoca e-dziennika mają charakter ogólny, czy szczegółowy?

2.4. Czy e-dziennik ułatwia przepływ informacji pomiędzy wychowawcą a opiekunami prawnymi dziecka?

2.5. Czy stosowanie e-dziennika wptywa na zmniejszenie się liczby problemów szkolno-wychowawczych?

Istotność statystyczna oraz kierunek zależności zostały sprawdzone za pomocą testu Chi kwadrat niezależności, jak również przy użyciu odpowiednio dobranych statystyk.

\section{WNIOSKI Z BADAŃ}

Na podstawie ankiet przeprowadzonych wśród nauczycieli edukacji wczesnoszkolnej można wywnioskować, że ok. 81,75\% całkowicie akceptuje pracę z dziennikiem elektronicznym. W licznych wypowiedziach poddani badaniu nauczyciele zaznaczali, że:

Praca z e-dziennikiem jest przede wszystkim wygodna.

Umożliwia wgląd do danych $w$ dowolnym miejscu i czasie (wystarczy dostęp do Internetu).

... już nie muszę siedzieć godzinami i spisywać ocen na kartkę lub obliczać ich średnich, takie zadania wykonuje za mnie e-dziennik.

Usprawniła się komunikacja z rodzicami, teraz aby omówić zachowanie ucznia nie trzeba czekać a ż do wywiadówki.

Pozytywny odbiór e-narzędzia wiąże się bezpośrednio ze świadomością korzyści wynikających z jego użytkowania. Szczególnie ważna 
według nauczycieli jest możliwość szybkiego wykonywania różnego typu zestawień oraz łatwiejszego (niż w przypadku trakcyjnych dzienniczków) kontaktu z rodzicami ucznia. Wśród głównych czynników sprzyjających akceptacji narzędzia pedagodzy wymieniali:

- łatwość obsługi - ok. 80,95\% ankietowanych;

- brak konieczności noszenia ze sobą dziennika - ok. 71,42\% odpowiadających;

- nieograniczony dostęp do dokumentacji, możliwość uzupełnienia danych również w domu - ok. 77,78\% badanych;

- możliwość szybkiego nawiązania kontaktu z większością rodziców - ok. 68,25\% nauczycieli;

- pomoc w przygotowaniu do wywiadówek oraz Rad Pedagogicznych dzięki opcji automatycznego wyliczania średnich ocen, zestawiania obecności itp. - ok. 80,95\% badanych;

Głównym powodem braku akceptacji dla pracy z e-dziennikiem było:

- negatywne nastawienie do narzędzi technologii informacyjnej, a w konsekwencji podważanie sensu oraz potrzeby stosowania jej - ok. 15,07\% pedagogów;

- niewystarczający poziom wiedzy oraz umiejętności obsługi, a w konsekwencji wysoki poziom stresu związany z użytkowaniem elektronicznego dziennika - ok. 18,25\% ankietowanych.

Do problemów związanych z użytkowaniem e-dziennika, a tym samym do braku akceptacji narzędzia przyznaje się średnio co piątą osoba $(18,25 \%)$. Przeprowadzona analiza wykazała istnienie istotnej statystycznie zależności pomiędzy wiekiem oraz poziomem akceptacji narzędzia. Nauczyciele niechętnie korzystający z elektronicznego dziennika należeli do grupy osób powyżej 50 roku życia, unikającej stosowania technologii informacyjnej oraz szkoleń organizowanych w tym obszarze. Tymczasem, jak donoszą wyniki badań, prawidłowa praca z nowoczesnymi urządzeniami TI wymaga zaangażowania, opanowania podstawowej wiedzy i umiejętności korzystania z komputera oraz z sieci Internet, jak również systematyczności związanej nieustannym nabywaniem nowych kompetencji. Zgodnie z uwagami na- 
uczycieli, w przypadku problemów związanych z obsługą e-narzędzia większość z nich korzysta się z pomocy administratora lub nauczyciela informatyki zatrudnionego w szkole (zazwyczaj jest to ta sama osoba).

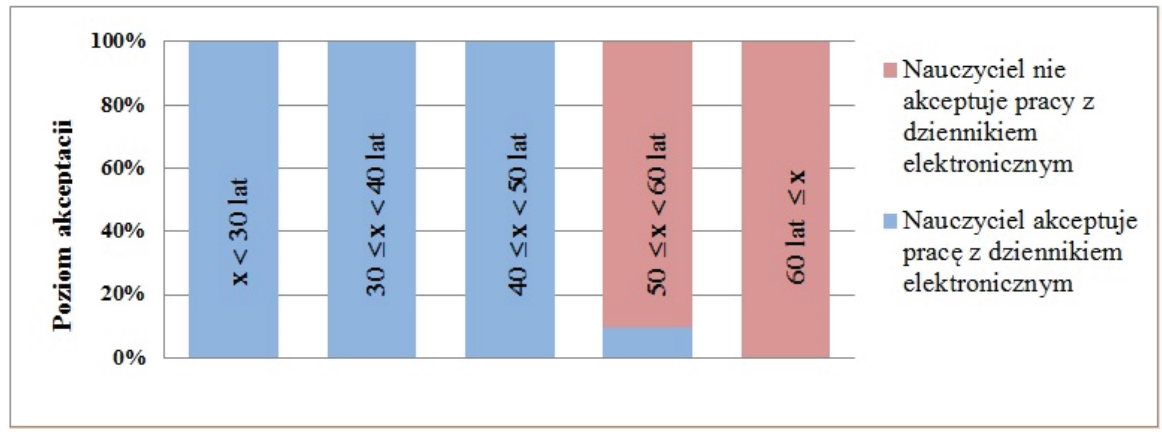

Wyk. 1. Poziom akceptacji e-dziennika w kontekście wieku nauczyciela

Źródło: Opracowanie własne.

Analiza sposobu wykorzystania dziennika elektronicznego przez nauczycieli wykazała, że usprawnia on działania związane z procesem:

\section{- Nauczania}

- łatwiejsza niż w przypadku tradycyjnego dziennika (dzięki opcji automatycznego zestawiania) możliwość analizowania aktywności oraz wyników pracy ucznia;

- narzędzie umożliwia planowanie tematów zajęć z uwzględnieniem całego roku szkolnego (część dzienników ma wbudowaną funkcję importowania tematów lekcji do dziennika z dokumentów tekstowych np. typu Microsoft Office Word);

- szybki kontakt z rodzicami i możliwość przekazania informacji na temat: postępów lub problemów występujących w toku nauczania, planowanej klasówki, zmiany planu zajęć itp.;

- możliwość wystawiania ocen, nadawania im konkretnej wagi itd. 


\section{- Wychowania uczniów}

- narzędzie ułatwia kontakt z rodzicami, dzięki czemu łatwiej jest ustalić wspólny front działania na linii szkoła-dom, co w przypadku problemów wychowawczych jest niezmiernie istotne;

- e-dziennik ułatwia kontakt z gronem pedagogicznym, co umożliwia konsultowanie zachowania dziecka z innymi nauczycielami.

- Przygotowania dokumentacji szkolnej

- narzędzie umożliwia przygotowanie zestawień związanych z nieobecnościami dzieci, ich spóźnieniami itp. niezbędnych podczas zebrań z rodzicami lub posiedzeń Rady Pedagogicznej,

- pomocne przy wypełnianiu świadectw na koniec roku ${ }^{21}$.

Wykorzystanie elektronicznego dziennika do kontaktu z rodzicami deklaruje średnio ok. 81,75\% nauczycieli. Za pomocą poczty wychowawcy przypominają o klasówkach, materiałach niezbędnych do realizacji zajęć plastycznych itp. E-narzędzie wykorzystywane jest również do informowania rodziców o sytuacji szkolno-wychowawczej dziecka. Oczywiście stopień użytkowania e-dziennika nie jest równomierny i w przypadku uczniów sprawiających problemy wychowawcze okazuje się częstszy. Wypowiedzi nauczycieli świadczą jednak o tym, że część rodziców - ok. 16\% (pomimo młodego wieku) nie weryfikuje regularnie konta e-mail powiązanego z e-dziennikiem, co utrudnia wspólne działanie oraz wymianę informacji na temat wyników nauczania oraz zachowania dziecka. Wśród przyczyn powyższego zjawiska wymienia się: ograniczony dostęp do Internetu oraz sprawnie działającego sprzętu komputerowego, brak nawyku codziennego sprawdzania poczty powiązanej z e-narzędziem, zbyt dużą ilość obowiązków i brak czasu² ${ }^{22}$.

21 Zestawienie przygotowane na podstawie odpowiedzi nauczycieli, którzy korzystali z różnych typów e-dziennika.

22 Diagnoza społeczna 2013. Warunki i jakość życia Polaków, pod red. J. Czapińskiego, T. Panek, Warszawa 2014, s. 357-384, http://analizy.mpips.gov.pl/ 
W wielu szkołach e-dziennik zastąpił tradycyjne dzienniczki ucznia. Analiza sytuacji wykazuje jednak, że pomimo dostępu do e-narzędzia część nauczycieli $(18,25 \%)$ nadal korzysta z papierowych zeszytów do korespondencji, charakteryzując tę formę jako bardziej naturalną i sprawiającą mniej problemów.

Na podstawie zgromadzonych danych można wnioskować, że nauczyciele korzystają z opcji e-wiadomości głównie w celu poinformowania rodziców o niewłaściwym zachowaniu ucznia $(48,41 \%$ pedagogów). W badanej grupie znalazły się jednak osoby (32,54\%), które regularnie, zazwyczaj pod koniec tygodnia, wysyłały do rodziców wiadomości mające charakter sprawozdania zawierającego również informacje pozytywne oraz pochwały. Prowadzona korespondencja ma charakter szczegółowy i wyczerpujący. Nauczyciele korzystający z e-dziennika zaznaczają, że elektroniczna forma komunikacji oraz dostęp do konta chronionego hasłem zapewnia zarówno im, jak też rodzicom zachowanie pełnej prywatności, co w przypadku tradycyjnych zeszytów uwag nie było możliwe.

Na podstawie zgromadzonych danych można wywnioskować, że możliwość stałego kontaktu z rodzicami przy pomocy e-narzędzia nie wyeliminowała całkowicie negatywnych zjawisk związanych z zachowaniem uczniów. Pojawiające się problemy w szczególności dotyczą dzieci, których rodzice nie współpracują ze szkołą. Na podstawie szacunków dokonanych przez pedagogów można orzec, że wspomniany problem dotyczy średnio 16\% rodzin (ok. 4 uczniów w klasie 25-osobowej). W przypadku dzieci, których rodzice mają dobry kontakt z wychowawcą, występuje zmniejszenie skali zjawiska:

- wagarowania oraz spóźnień na zajęcia, co podkreśla 80,16\% nauczycieli;

- nieodpowiedniego przygotowania do lekcji, według 70,63\% ankietowanych

- niewłaściwych i ganionych przez nauczyciela zachowań $78,57 \%$ nauczycieli.

images/stories/publ_i_raporty/DS2013/Raport_glowny_Diagnoza_Spoleczna_ 2013.pdf (dostęp: 06.1̄1.2015). 


\section{Podsumowanie}

Dzienniki elektroniczne, chociaż wykorzystywane są w szkołach od niedawna, już zyskały rzeszę zwolenników. Z całą pewnością przyczyniają się do tego funkcje e-narzędzia, ułatwiające szereg zadań związanych z organizacją codziennej pracy pedagoga. Według autorki na szczególną uwagę zasługuje jednak moduł wiadomości, umożliwiający szybki kontakt z rodzicami ucznia, a w konsekwencji płynną wymianę wiadomości na temat zachowania oraz problemów edukacyjnych dziecka. Zrealizowane badania wykazują, że regularne i konsekwentne użytkowanie narzędzia w celu wymiany informacji na linii szkoła-dom koreluje ze spadkiem liczby negatywnych zachowań. Należy zatem w dalszym ciągu edukować zarówno nauczycieli, jak i rodziców, tak aby w sposób świadomy mogli oni korzystać z walorów elektronicznego dziennika.

\section{Summary}

ELECTRONIC CLASS REGISTER IN SCHOOL TEACHERS' JOB

The objective of this article is to discuss the results of a study concerning the use of electronic class registers in primary school teachers' job. Information on the level of the acceptance of tools and problems with their use has been included in the materials. The author of these studies has also examined the relationship between the use of the tools and the number of school and educational problems in the classroom. 